Marek Miszczyński OFMCap

Pontificia Università Antonianum, Rzym

\title{
Minoritas według św. Franciszka z Asyżu w ujęciu chrystologicznym
}

Minoritas to bardzo bogate znaczeniowo pojęcie. Już sama próba przetłumaczenia go na język polski nastręcza pewnych trudności: Tłumaczy się je często jako mało ść, ale to nie oddaje całej jego głębi znaczeniowej. Bliższe znaczeniu oryginalnemu jest tłumaczenie zawarte w nazwie zakonu założonego przez Franciszka z Asyżu: bracia m n i ej s i. Oddaje ono bowiem ideę dynamiki relacyjnej zawartej w minoritas - można być mniejszym zawsze w odniesieniu do czegoś lub kogoś. Tym niemniej pojęcie to nie wyczerpuje się tylko w tej idei. Nie chcąc zawężać $\mathrm{z}$ góry szerokiego zakresu znaczeniowego tego pojęcia, będę je stosować bez tłumaczenia, zachowując formę oryginalną w języku łacińskim: minoritas. Z pewnością, aby wydobyć całe bogactwo jego treści, należałoby przebadać je z różnych perspektyw: lingwistycznej, społecznej, antropologicznej, historycznej, teologicznej itd. Takie interdyscyplinarne podejście mogłoby dać w miarę wyczerpującą odpowiedź na pytanie, jak Franciszek rozumiał minoritas? Co dla niego oznaczało bycie bratem mniejszym? Nie pretendując do wyczerpującego opracowania, zamierzam wybrać jedną ze wspomnianych perspektyw i przez nią zbliżyć się do znaczenia minoritas u Franciszka z Asyżu.

Na temat minoritas zostało napisane wiele opracowań w różnych ujęciach. Odsyłam do hasła „minoritas” w Leksykonie duchowości franciszkańskiej: J. Micò OFMCap, Minoritas, [w:] 
Podobnie jak dla każdego założyciela nowej formy życia w Kościele, tak też i dla Franciszka głównym punktem odniesienia dla sposobu życia obranego przez niego, a więc także dla tego aspektu, który określić można jako minoritas, była nie tyle sytuacja społeczna panująca w jego czasach ani nie różne nurty duchowości w tradycji Kościoła ani nie filozoficzne dysputy na temat sensu życia, ale Ewangelia rozumiana dzięki światłu Ducha Świętego w całej swej prostocie i radykalizmie. Z pewnością odegrały też w tym swoją rolę kultura feudalna, w której żył, tradycja Kościoła, w której wyrósł, konfrontacja z innymi, której szczerze szukał, tym niemniej jednak podstawowym źródłem inspiracji była osoba Chrystusa, którego poznał w Ewangelii i którym się zachwycił: „Nikt nie mówił mi, jak mam żyć, ale sam Najwyższy objawił mi, że mam żyć według Ewangelii" - wspomina sam Franciszek w swoim Testamencie ${ }^{2}$. Dlatego zasadna wydaje się próba wydobycia znaczenia, jakie miała dla Franciszka minoritas przede wszystkim w ujęciu chrystologicznym. Na ile poznanie Chrystusa zadecydowało, że minoritas stała się jednym z podstawowych elementów charyzmatu Franciszka? Jakie aspekty tajemnicy Chrystusa mogły wpłynąć na Franciszka tak bardzo, że założony przez siebie zakon nazwał braćmi mniej szy mi?

Punktem wyjścia będzie dla mnie wyodrębnienie i przeanalizowanie fragmentów pism Biedaczyny z Asyżu, w których pojawia się słowo minor $\mathrm{z}$ bezpośrednim odniesieniem do Ewangelii. W ten sposób postaram się ukazać związek pomiędzy rozumieniem minoritas przez Franciszka i obrazem Chrystusa, który je inspirował. Następnie postaram się przybliżyć i pogłębić ten szczególny obraz Chrystusa w kontekście całego korpusu pism Świętego i jego biografii.

\footnotetext{
Leksykon duchowości franciszkańskiej, przekł. Ch. J. Fryc, Kraków-Warszawa 2006, kol. 919-938; a także do zbioru artykułów w Minores et subditi omnibus. Tratti caratterizzanti dell'identità francescana, a cura di L. Padovese, Roma 2003. Warto także sięgnąć do F. Ossanna, R. Carboni, G. Lupi, La minorità francescana nel cammino formativo, Padova 1999.

T 14; używam skrótów pism św. Franciszka według: Źródła franciszkańskie, red. R. Prejs, Z. Kijas, Kraków 2005, s. 9-11.
} 


\section{Minor w Pismach św. Franciszka}

Na samym początku trzeba stwierdzić, że słowo minoritas nie występuje ani razu w pismach św. Franciszka. Jest to dość zrozumiałe, jeśli się weźmie pod uwagę fakt, że pojęcie to jest abstrakcyjne, a święty z Asyżu zarówno w życiu, jak i w sposobie wyrażania był człowiekiem bardzo konkretnym. W swoich pismach mówi o bracie lub o braciach mniejszych; minoritas stosuje do konkretnych osób. W korpusie pism znajduje się zatem słowo minor ${ }^{3}$, które użyte jest 13 razy w odniesieniu do braci (jeden raz w odniesieniu do czasu ${ }^{4}$ ), z czego pięć razy z wyraźnymi cytatami lub aluzjami do Biblii, szczególnie do Ewangelii:

\begin{tabular}{|l|l|l|l|}
\hline 1 Reg 6,3 & $\begin{array}{l}\text { Et nullus vocetur prior, } \\
\text { sed generaliter omnes vo- } \\
\text { centur fratres min ores. } \\
\text { Et alter alterius lavet pedes. }\end{array}$ & $\begin{array}{l}\text { I nikogo nie można nazy- } \\
\text { wać przeorem, lecz wszy- } \\
\text { scy bez różnicy niech na- } \\
\text { zywają się braćmi mniej- }- \\
\text { szymi. I jeden drugiemu } \\
\text { niech umywa nogi. }\end{array}$ & $\begin{array}{l}\text { uczyciel, umyłem wan i Na- } \\
\text { nogi, to i wyście powinni } \\
\text { sobie nawzajem umywać } \\
\text { nogi (J 13, 14). }\end{array}$ \\
\hline
\end{tabular}

3 Warto zauważyć, że generalnie w całym korpusie pism św. Franciszka odczuwa się pewną niechęć do wszystkiego, co ma związek z ideą wyższości. Widać to w negatywnym znaczeniu, jakie zwykle przypisywane jest terminom takim jak magnus, magister, magnatus, prior, superior, superbus.

42 Reg 8, 3: „Quo decedente, electio successoris fiat a ministris provincialibus et custodibus in capitulo Pentecostes, in quo provinciales ministri tenenantur semper insimul convenire, ubicumque a generali ministro fuerit constitutum; et hoc semel in tribus annis vel ad alium terminum maiorem vel mi nor e m".

5 Problematykę związaną z autorstwem cytatów biblijnych w pismach św. Franciszka dobrze omawia O. van Asseldonk w La lettera e lo Spirito, t. II, Roma 1985, s. 359-396. W omawianym przypadku istnieją dwie przesłanki wskazujące na to, że wyodrębnione cytaty biblijne pochodzą od samego Franciszka, a nie od eksperta, z którego pomocy niewątpliwie korzystał. Pierwsza to fakt, że te same odniesienia biblijne znajdują się nie tylko w Regule, przy której redakcji Franciszek korzystał z pomocy ekspertów, ale także w innych jego pismach. To sugeruje, że te fragmenty biblijne były mu bliskie, oraz wskazuje na głęboko zasymilowaną fundamentalną ideę w nich zawartą, wyrażaną przy różnych okazjach. Druga przesłanka to fakt, że przytoczone fragmenty biblijne zasadniczo cytowane są z dość dużą swobodą, co wskazuje na troskę nie tyle o poprawność i zgodność cytowania, właściwą dla eksperta, ile o przekazanie zasadniczej myśli w nich zawartej. 


\begin{tabular}{|c|c|c|c|}
\hline $2 \mathrm{Lw} 87$ & $\begin{array}{l}\text { Ego frater Franciscus, } \\
\text { min or servus vester, } \\
\text { rogo et obsecro vos in ca- } \\
\text { ritate, quae Deus est, et } \\
\text { cum voluntate osculandi } \\
\text { vestros pedes, quod haec } \\
\text { verba et alia Domini no- } \\
\text { stri Jesu Christi cum hu- } \\
\text { militate et caritate debe- } \\
\text { atis recipere et operari et } \\
\text { observare. }\end{array}$ & $\begin{array}{l}\text { Ja, brat Franciszek, słu- } \\
\text { ga wasz naj mniejszy, } \\
\text { proszę was i zaklinam } \\
\text { w miłości, która jest Bóg } \\
\text { i z chęcią ucałowania wa- } \\
\text { szych stóp, abyście te } \\
\text { oraz inne słowa Pana na- } \\
\text { szego Jezusa Chrystusa } \\
\text { przyjęli z pokorą i miłoś- } \\
\text { cią i spełniali je, i zacho- } \\
\text { wywali. }\end{array}$ & $\begin{array}{l}\text { Myśmy poznali i uwie- } \\
\text { rzyli miłości, jaką Bóg ma } \\
\text { ku nam. Bóg jest miłoś- } \\
\text { cią: kto trwa w miłości, } \\
\text { trwa w Bogu, a Bóg trwa } \\
\text { w nim (1 J 4,16). }\end{array}$ \\
\hline $1 \operatorname{Reg} 5,9-12$ & $\begin{array}{l}\text { Similiter omnes fratres } \\
\text { non habeant in hoc po- } \\
\text { testatem vel dominatio- } \\
\text { nem maxime inter se. Si- } \\
\text { cut enim dicit Dominus in } \\
\text { evangelio: „Principes gen- } \\
\text { tium dominantur eorum, et } \\
\text { qui maiores sunt potestatem } \\
\text { exercent in eos”, non sic erit } \\
\text { inter fratres; et quicumque } \\
\text { voluerit inter eos maior fieri } \\
\text { sit eorum minister et servus; } \\
\text { et qui maior est inter eos fiat } \\
\text { sicut min or. }\end{array}$ & $\begin{array}{l}\text { Nie wolno również bra- } \\
\text { ciom piastować władzy } \\
\text { ani panować nad nikim, } \\
\text { zwłaszcza nad współbrać- } \\
\text { mi. Tak bowiem Pan mówi } \\
\text { w Ewangelii: „Władcy pa- } \\
\text { nują nad narodami, a moż- } \\
\text { ni sprawuja nad nimi wła- } \\
\text { dzę”. Nie tak będzie wśród } \\
\text { braci; i kto by chciał być } \\
\text { wśród nich większy, niech } \\
\text { będzie ich ministrem i sługa, } \\
\text { i kto wśród nich jest więk- } \\
\text { szy, niech, stanie się jako } \\
\text { mniejszy. }\end{array}$ & $\begin{array}{l}\text { Wiecie, że władcy naro- } \\
\text { dów uciskają je, a wiel- } \\
\text { cy dają im odczuć swą } \\
\text { władzę. Nie tak będzie } \\
\text { u was. Lecz kto by mię- } \\
\text { dzy wami chciał stać się } \\
\text { wielkim, niech będzie } \\
\text { waszym sługą. A kto by } \\
\text { chciał być pierwszym } \\
\text { między wami, niech bę- } \\
\text { dzie niewolnikiem wa- } \\
\text { szym, na wzór Syna } \\
\text { Człowieczego, który nie } \\
\text { przyszedł, aby Mu służo- } \\
\text { no, lecz aby służyć i dać } \\
\text { swoje życie na okup za } \\
\text { wielu (Mt 20, 25-28). } \\
\text {...największy między wami } \\
\text { niech będzie jak najmłod- } \\
\text { szy, a przełożony jak słu- } \\
\text { ga! Któż bowiem jest więk- } \\
\text { szy? Czy ten, kto siedzi za } \\
\text { stołem, czy ten, kto służy? } \\
\text { Czyż nie ten, kto siedzi za } \\
\text { stołem? OtóżJa jestem po- } \\
\text { śród was jak ten, kto służy } \\
\text { (Łk 22, 26-27). }\end{array}$ \\
\hline $2 \mathrm{Lw} 42$ & $\begin{array}{l}\text { Cui autem obedientia } \\
\text { commissa est et qui habe- } \\
\text { tur maior, sit sicut minor } \\
\text { et aliorum fratrum servus. }\end{array}$ & $\begin{array}{l}\text { Ten zaś, który ma czu- } \\
\text { wać nad posłuszeństwem } \\
\text { i który uchodzi za więk- } \\
\text { szego, niech będzie jako } \\
\text { mniejszy i sługa in- } \\
\text { nych braci. }\end{array}$ & $\begin{array}{l}\text {...największy między wami } \\
\text { niech będzie jak najmłod- } \\
\text { szy, a przełożony jak słu- } \\
\text { ga! Któż bowiem jest więk- } \\
\text { szy? Czy ten, kto siedzi za } \\
\text { stołem, czy ten, kto służy? } \\
\text { Czyż nie ten, kto siedzi za } \\
\text { stołem? Otóż Ja jestem po- } \\
\text { śród was jak ten, kto służy } \\
\text { (Łk 22, 26-27). }\end{array}$ \\
\hline
\end{tabular}




\begin{tabular}{|c|c|c|c|}
\hline $1 \operatorname{Reg} 23,7$ & $\begin{array}{l}\text { humiliter rogamus et sup- } \\
\text { plicamus nos omnes fra- } \\
\text { tres min or es, servi inu- } \\
\text { tiles, ut omnes in vera fide } \\
\text { et poenitentia persevere- } \\
\text { mus, quia aliter nullus sal- } \\
\text { vari potest. }\end{array}$ & $\begin{array}{l}\text {...my wszyscy bracia } \\
\text { mniejs i, studzy nieuży- } \\
\text { teczni, pokornie prosimy } \\
\text { i błagamy, abyśmy wszy- } \\
\text { scy wytrwali w prawdzi- } \\
\text { wej wierze i pokucie, bo } \\
\text { inaczej nikt nie może być } \\
\text { zbawiony. }\end{array}$ & $\begin{array}{l}\text { Tak mówcie i wy, gdy } \\
\text { uczynicie wszystko, } \\
\text { co wam polecono: Słu- } \\
\text { dzy nieużyteczni jeste- } \\
\text { śmy; wykonaliśmy to, co } \\
\text { powinniśmy wykonać } \\
\text { (Łk 17, 10). }\end{array}$ \\
\hline
\end{tabular}

Jak widać z powyższego zestawienia, dwa fragmenty pism św. Franciszka (1 Reg 5, 9-12 i 2 Lw 42), w których używa on słowo minor, nawiązują do pouczenia, którego Jezus udziela swoim uczniom o tym, kto jest największy i najważniejszy we wspólnocie (Łk 17, 10 i Mt 20,25-28), jeden (1 Reg 6, 3) do gestu umycia nóg uczniom przez Chrystusa (J 13, 14). Aluzji do tego gestu można się dopatrzyć także we fragmencie Listu do wiernych (2 Lw 87) razem z wyraźnym odniesieniem do pierwszego Listu św. Jana, który mówi o Bogu jako o Miłości $(1 \mathrm{~J} 4$, 16). W końcu fragment Reguły niezatwierdzonej nawiązuje do nauki Jezusa o pokorze (Łk 17, 10).

Już na pierwszy rzut oka widać wyraźne zestawienie pojęcia minoritas z ideą służby: bycie mniejszym oznacza przede wszystkim służenie na wzór Chrystusa. Warto przyjrzeć się teraz dokładniej poszczególnym fragmentom biblijnym w kontekście całego korpusu pism św. Franciszka, aby zbliżyć się do znaczenia minoritas dla świętego z Asyżu.

\section{Franciszkowe rozumienie minor według Łk 22, 26-27 i Mt 20, 25-28}

W dwóch wyodrębnionych fragmentach pism św. Franciszka, w których pojawia się słowo minor (1 Reg 5, 9-12 i 2 Lw 42), znajduje się odniesienie do tego samego pouczenia Chrystusa przytoczonego przez ewangelistę Łukasza (22, 26-27). Chodzi o naukę, której Jezus udziela swoim uczniom w kontekście ostatniej wieczerzy po sprzeczce, do której doszło między nimi na temat „kto z nich jest największy” (Łk 20, 24). Kontekst, w którym umiejscawia ją Łukasz, oraz zawarta w niej aluzja Jezusa do służenia przy stole nawiązują do opisanego przez Ewangelistę Jana (J 13,1-22) gestu umycia nóg uczniom przezJezusa. W dalszej części zajmę się osobno tym fragmentem. W tym miejscu warto zauważyć jeszcze powiązanie $\mathrm{z}$ innym fragmentem pochodzącym z Ewangelii Mateusza (20, 25-28), z której dokładnie zacytowano słowa Jezusa. Kontekst tego fragmentu jest co 
prawda inny od Łukaszowego - dotyczy oburzenia w grupie uczniów na dwóch spośród nich: Jana i Jakuba wskutek ich pragnienia zasiadania po prawicy Jezusa w Jego królestwie - tym niemniej zasadniczy temat nauki Jezusa jest ten sam: prawdziwą wielkość mierzy się umiejętnością służenia; nie ten jest wielki, kto panuje i pozwala się obsługiwać, ale ten, kto służy.

Postawa służby przeciwstawiona jest tutaj idei panowania. Jezus piętnuje charakterystyczną dla świata tendencję do dominowania nad innymi: „władcy narodów uciskająje, a wielcy dają im odczuć swą władzę". Swoim uczniom poleca natomiast: „Nie tak będzie u was”, a więc w sposobie sprawowania władzy i w ogóle w stylu życia mają się kierować innym kryterium: „Kto by między wami chciał stać się wielkim, niech będzie waszym sługą. A kto by chciał być pierwszym między wami, niech będzie niewolnikiem waszym". Brat mniejszy zatem to ten, który wyrzeka się dominowania nad innymi i dobrowolnie przyjmuje postawę sługi. Dotyczy to wszystkich braci ${ }^{6}$, dominować bowiem nad innymi można na różne sposoby: używając swojej inteligencji, wiedzy czy też funkcji; zarówno w sprawowanej posłudze, jak i w zwykłych codziennych relacjach międzyludzkich; wszędzie tam, gdzie ktoś chce pokazać swoją wyższość nad drugim.

Najbardziej na tę pokusę narażeni są przełożeni, dlatego do nich wyraźnie zwraca się Franciszek w Liście do wiernych, dając im wskazania samego Jezusa: „Ten zaś, który ma czuwać nad posłuszeństwem i który uchodzi za większego, niech będzie jako mniejszy i sługa innych braci”. Święty z Asyżu nawiązuje do tych słów Jezusa jeszcze w dwóch innych miejscach swoich pism, w obu w odniesieniu do przełożonych:

1 Reg 4, 6: „I ministrowie, i słudzy niech pamiętają, że Pan mówi: nie przyszedłem, aby Mi służono, lecz aby służyć, i że troska o dusze braci została im powierzona"7. Np 4, 1: „Nie przyszedłem, aby Mi służono, lecz aby służyć, mówi Pan. Ci, którzy są postawieni nad innymi, tak powinni się chlubić z tego przełożeństwa, jakby zostali wyznaczeni do obowiązku umywania nóg braciom"8.

6 Aktualnetłumaczenie najęzyk polski opuszcza zaimek, ,wszyscy”.W oryginale zdanie brzmi: "Similiter o mnes fratres non habeant in hoc potestatem vel dominationem maxime inter se (1 Reg 5, 9). Dosłownie zdanie to należałoby więc przetłumaczyć: „Podobnie niech w s zy s cy br aci a uważają, aby nie piastowali władzy ani nie panowali nad nikim, zwłaszcza nad współbraćmi”.

„Et recordentur ministri et servi, quod dicit Dominus: «Non veni ministrari sed ministrare»”.

„Non veni ministrari, sed ministrare, dicit Dominus. Illi qui sunt super alios constituti, tantum de illa praelatione glorientur, quantum si essent in abluendi fratrum pedes officio deputati". 
Warto zwrócić uwagę na to, jak Franciszek nazywa przełożonych: ministri et servi. W swoich pismach święty używa tego wyrażenia w odniesieniu do nich ponad 60 razy. To wskazuje na bardzo mocno zakorzenioną ideę minoritas jako służby, w przeciwieństwie do postawy panowania nad innymi. Franciszek nie chce, aby przełożony nazywał się „mag-ister”, ponieważ termin ten związany jest ze słowem „maior”, co oznacza „wielki”, ten, który panuje i któremu się służy. Chce natomiast, aby przełożonego nazywano „min-ister”, nawiązując przez to do minoritas, oraz „sługa”, doprecyzowując w ten sposób swoją myśl: „przełożony ma być pierwszym spośród braci mniejszych, który służy".

Tak pojęta służba nie oznacza oczywiście oddania się do dyspozycji innych w sensie „robienia tego, co polecają”. Oznaczałoby to ucieczkę od posługi, do jakiej wezwany jest przełożony. Z racji pełnionej funkcji jest on powołany do podejmowania decyzji, napominania i poprawiania braci. Chodzi o to jednak, aby nie czynił tego z pozycji wyższego, z chęci dominacji nad innymi, ale z „miłością, dobrocią i serdecznością”, wówczas bowiem okazuje się sługą i ministrem, bratem prawdziwie mniejszym. Postawę tę trafnie opisuje sam Franciszek słowami swoich biografów:

Kiedyś [Franciszek] powiedział do swego socjusza: „Nie widziałbym się bratem mniejszym, gdybym nie był w takim stanie, jaki ci opiszę”. Rzekł: „Oto, będąc przełożonym braci, idę na kapitułę, przemawiam, upominam braci, a na końcu mówią przeciw mnie: «Nie odpowiada nam nieuk i człek wzgardzony, dlatego nie chcemy, byś rządził nami; jesteś bowiem prostak, niemy i głupiec». Potem wyrzucają mnie z urąganiem, przez wszystkich wzgardzonego. Mówię ci, że gdybym tych słów nie wysłuchał z tą samą twarzą, z tą samą radością ducha, z tą samą decyzją dążenia do świętości, to nie byłbym wcale bratem mniejszym"10.

W takich sytuacjach jak opisana powyżej przez Franciszka pojawia się ze szczególną wyrazistością pokusa użycia władzy jako środka dominacji nad innymi lub też pokusa zniechęcenia i rezygnacji z pełnionej posługi. Bycie mniejszym oznacza wytrwanie w posłudze „z tą samą radością ducha i z tą samą decyzją dążenia do świętości”, ale jednocześnie bez gniewu i chęci pokazania, „kto tu rządzi”, „z tą samą twarzą”.

Por. 2 Reg 10, 5-6.

10 2 Cel 145; por. też 1 B 6, 5; ZA 109; 2 Zw 64. 
Postawę służby w duchu minoritas ukazuje najlepiej przykład samego Jezusa w geście umycia nóg.

\section{Franciszkowe rozumienie minor według J 13, 14}

W szóstym rozdziale Reguły niezatwierdzonej poświęconym relacji między przełożonymi i pozostałymi braćmi we wspólnocie Franciszek nawiązuje do trzynastego rozdziału Ewangelii Jana, w którym opisana jest scena umycia nóg uczniom przez Jezusa podczas ostatniej wieczerzy (J 13, 1-17). Słowa Jezusa skierowane do uczniów po dokonanym geście, w których podkreśla On potrzebę służenia, są analogiczne do powyżej analizowanych pouczeń przytoczonych przez Mateusza i Łukasza. Nowością w omawianym fragmencie z Ewangelii Jana jest fakt, że Jezus sam pokazuje, jak należy służyć. Nie tylko naucza, ale sam daje przykład, umywając nogi swoim uczniom. Być może przez to fragment ten należy do jednego z najbardziej uprzywilejowanych przez Franciszka ${ }^{11}$. Świadczy o tym znany z biografii fakt z ostatnich chwil życia Biedaczyny z Asyżu, kiedy to tuż przed śmiercią polecił, aby czytano mu ten właśnie fragment z Ewangelii Jana ${ }^{12}$. Świadczą o tym także odniesienia do niego w innych miejscach pism świętego. Jedno wyraźne i bezpośrednie znajduje się w przytoczonym już wyżej Napomnieniu 4:

Ci, którzy są postawieni nad innymi, tak powinni się chlubić z tego przełożeństwa, jakby zostali wyznaczeni do obowiązku umywania nóg braciom. I jeśli utrata przełożeństwa zasmuca ich bardziej niż utrata obowiązku umywania nóg, tym więcej napełniają sobie trzosy z niebezpieczeństwem dla duszy ${ }^{13}$.

Z powyższego napomnienia wynika, że obowiązek umywania nóg braciom dotyczy przełożonych, ale w szóstym rozdziale Reguły niezatwierdzonej, podobnie jak w omawianym wyżej piątym tej samej Reguły, Franciszek

11 Por. O. van Asseldonk, Insegnamenti biblici ,privilegiati” negli scritti di san Francesco d'Assisi, „Analecta OFMCap” 95 (1979), s. 146-165.

12 Por. 1 Cel 110; 2 Cel 217; 1 B 14, 5.

13 „Illi qui sunt super alios constituti, tantum de illa praelatione glorientur, quantum si essent in abluendi fratrum pedes officio deputati. Et quanto magis turbantur de ablata sibi praelatione quam de pedum officio, tanto magis sibi loculos ad periculum animae componunt". 
obejmuje nim także pozostałych braci: „wszyscy bez różnicy niech nazywają się braćmi mniejszymi i niech jeden drugiemu umywa nogi”.

Jakie znaczenie idei minoritas nadaje ewangeliczny gest umycia nóg? Aby odpowiedzieć na to pytanie, trzeba spojrzeć przede wszystkim na samego autora tego gestu. Ewangelista Jan pisze, że Chrystus ,wstał od wieczerzy i złożył szaty, a wziąwszy prześcieradło, nim się przepasał”: zdjął szaty Pana i Nauczyciela, a przywdział ubiór charakterystyczny dla sług i niewolników. „Potem nalał wody do miednicy i zaczął umywać uczniom nogi, ocierając je prześcieradłem, którym był przepasany": uczynił to, co należy do obowiązków sług i niewolników. Z tych czynności wyłania się wyraźnie figura Chrystusa Sługi.Jest to obraz Chrystusa, który należał do najczęściej komentowanych w średniowieczu. Łączono go często z syntetycznym opisem całej misji Chrystusa, znajdującym się w liście do Filipian 2, 5-11 ${ }^{14}$,którego echo można znaleźć także w pismach św. Franciszka ${ }^{15}$.Zestawiając te dwa fragmenty podkreśla się fakt, że Chrystus nie tylko przyjął obowiązki sługi, ale przede wszystkim stan bycia sługą. Stając się człowiekiem, nie przyjął jedynie jego wyglądu zewnętrznego, ale wszystkie związane z tym ułomności, ograniczenia i słabości. Prawdziwie „ogołocił samego siebie, przyjąwszy postać sługi". Temu aktowi odpowiada gest zdjęcia szat przez Chrystusa podczas ostatniej wieczerzy i przepasanie się prześcieradłem, aby móc umyć nogi uczniom. Są to szaty Pana i Nauczyciela, które symbolizują naturę boską Syna Bożego, prześcieradło natomiast obrazuje naturę ludzką, przyjętą przez Niego. Pozostając nadal Panem i Nauczycielem, Jezus nie tylko wykonuje czynności sługi, ale przyjmuje jego postać, przepasując się prześcieradłem. Mógł wykonać ten gest w swoich szatach, ale zdjął je i przyodział się w inne, aby wskazać nie tylko na czynność, gest, ale także na stan, sposób bycia. Paweł ujmuje to w słowa: „Chrystus nie skorzystał ze sposobności, aby na równi być z Bogiem, lecz ogołocił samego siebie, przyjąwszy postać sługi”.

14 W kontekście Chrystusa Sługi komentowano również analizowane wyżej fragmenty Mt 20, 25-28 i Łk 22, 26-27, a także inne: Ps 21; Iz 42, 1-9; Iz 49, 1-7; Iz 50, 4-11; Iz 52, $13-$ 53; 1 Pt 2, 21-25. Por. Miguel Angel Lavilla Martín, La imagen del siervo en el pensamiento de san Francisco de Asís, según sus escritos, Valencia-Asís 1995, s. 122-153.

15 Najbardziej wyraźnie w 2 Lw 4-14. 
Wyłania się stąd kolejne znaczenie minoritas, jakim jest rezygnacja z przywilejów. Brat mniejszy to ktoś, kto umie dobrowolnie zrezygnować z tego, co mu przysługuje, z czego może korzystać. Czyni tak zarówno w stosunku do tego, co przysługuje jemu samemu, jak i z racji posługi dla innych. Franciszek miał świadomość, że szczególnie w tej drugiej dziedzinie istnieje subtelna pokusa prowadząca do nadużyć; ukrywa się bowiem pod płaszczem motywacji na pozór szlachetnej: „, to nie dla mnie, ale dla innych". Święty z Asyżu zachowuje jednak jasność myślenia i stanowczość w tym względzie. Obrazuje to następujący dialog z braćmi zawarty w biografiach świętego:

Podobnie powiedzieli niektórzy bracia do błogosławionego Franciszka: „Ojcze, czyż nie widzisz, że niekiedy biskupi nie pozwalają nam głosić kazań i pozwalają przez wiele dni, abyśmy stali w jakiejś okolicy bezczynni, zanim wolno nam przemawiać do ludu? Byłoby lepiej, gdybyś uzyskał dla braci przywilej od pana papieża, z korzyścią dla zbawienia dusz”. On odpowiedział im z wielkim wyrzutem, mówiąc: „Wy, bracia mniejsi, nie znacie woli Bożej i nie pozwalacie mi nawrócić całego świata, jak tego chce Bóg. Bo ja chcę przez pokorę i szacunek najpierw nawrócić prałatów, a gdy oni zobaczą wasze święte życie i wasz szacunek dla duchownych, sami poproszą was, abyście głosili kazania i nawracali lud. I nawet polecą was lepiej niż przywileje, których pragniecie, a które doprowadzą was do pychy. A jeśli wyzbędziecie się wszelkiej chciwości i zachęcicie ludzi, aby przyznali kościołom ich prawa, to oni poproszą was, abyście słuchali spowiedzi ich ludu; jednakże o to nie powinniście się troszczyć, gdyż jeśli się nawrócą, łatwo znajdą spowiedników. Ja dla siebie pragnę od Pana tego przywileju, aby mianowicie nie mieć żadnego przywileju od ludzi, a tylko wszystkim okazywać szacunek i, przez posłuszeństwo dla świętej reguły, przykładem bardziej niż słowem wszystkich nawrócić"16.

Naśladując przykład Chrystusa Sługi, minoritas nie idzie po linii efektywności, którą gwarantują przywileje, ale świadectwa życia. Posiada w ten sposób o wiele większą siłę przekonywania i o wiele szerszy zasięg oddziaływania.

Z rezygnacją z przywilejów związany jest brak ochrony i jakichkolwiek zabezpieczeń. Sługa nie jest chroniony prawem, jak jego pan. Ochroną może go otoczyć jedynie jego pan. Brat mniejszy zatem to także ten, który żyje bez zabezpieczeń, zdając się na Opatrzność Tego, o którym wie, że jest jego Ojcem. Wie, że nie mając zabezpieczeń, może się spotkać z upokorzeniem i wzgardaą, ale pokłada ufność w Bogu i w Nim odnajduje siłę.

16 ZA 20; por. także 2 Zw 50 oraz T 25-26. 
Upodabnia się w ten sposób do Chrystusa, cierpiącego Sługi Jahwe, który „nie zasłonił swojej twarzy przed zniewagami i opluciem” (Iz 50, 6) i doznał upokorzenia, ale doświadczył jednocześnie pomocy Boga, dlatego okazał się „nieczuły na obelgi, uczynił swoją twarz jak głaz i wstydu nie doznał" (Iz 50, 7). Franciszek nawiązuje do tego właśnie fragmentu z księgi Izajasza, kiedy wskazuje w Regule niezatwierdzonej na upokorzenia, na jakie narażeni są bracia proszący o jałmużnę, ale zachęca ich jednocześnie do pokładania ufności w Bogu ${ }^{17}$.

Dwa powyższe znaczenia minoritas dotyczą sposobu bycia jako sługi. Z tego wynika także wszystko to, co czyni sługa. Podejmuje się on zwykle czynności najniższych, których panowie nie wykonują. Nie oznacza to, że panowie nie pracują, ale że nie wykonują zwykle pewnych czynności, np. nie umywają nóg (czynność ta należała w starożytności do obowiązków sług i niewolników). Brat mniejszy zatem to ten, który gotów jest podjąć się takich czynności, które inni wykonują niechętnie, świadom tego, że to wynika z jego bycia sługą. Nie czyni tego w poczuciu krzywdy czy niższości, ale z godnością płynącą z przykładu Chrystusa. U Franciszka widać to wyraźnie w jego posłudze trędowatym, której oddawał się sam i którą zalecał braciom ${ }^{18}$.

W pismach św. Franciszka oprócz wyraźnych odniesień do ewangelicznego gestu umycia nóg przez Jezusa, istnieją także nawiązania nie wprost, które ukazują kolejny aspekt znaczeniowy minoritas. Chodzi o List do wiernych oraz o Napomnienie 19:

2 Lw 87: „Ja, brat Franciszek, sługa wasz najmniejszy, proszę was i zaklinam w miłości, którą jest Bóg i z chęcią ucałowania waszych stóp, abyście te oraz inne słowa Pana naszego Jezusa Chrystusa przyjęli z pokorą i miłością i spełniali je, i zachowywali”19. Np. 19: „I błogosławiony jest ten sługa, który został wyniesiony wysoko nie z własnej woli i pragnie być zawsze pod stopami innych"20.

${ }_{17}$ Por. 1 Reg 9, 4. Aluzje do Chrystusa cierpiącego Sługi Jahwe znajdują się też w wielu innych miejscach pism św. Franciszka, szczególnie w Officium Passionis Domini.

18 T 1-3; $1 \operatorname{Reg} 9,2$.

19 „Ego frater Franciscus, minor servus vester, rogo et obsecro vos in caritate, quae Deus est, et cum voluntate osculandi vestros pedes, quod haec verba et alia Domini nostri Jesu Christi cum humilitate et caritate debeatis recipere et operari et observare".

${ }^{20}$ „Et beatus ille servus, qui non per suam voluntatem ponitur in alto et semper desiderat esse sub pedibus aliorum". 
Pierwszy to jeden z fragmentów wyodrębnionych do analizy, z tej racji, że zawiera termin minor z wyraźnym odniesieniem biblijnym. W tym wypadku dotyczy ono Pierwszego Listu św. Jana, w którym ewangelista mówi o Bogu jako o Miłości: „Bóg jest miłością: kto trwa w miłości, trwa w Bogu, a Bóg trwa w nim" (1 J 4, 6). Kontekst miłości oraz użyty obraz ucałowania stóp pozwala na skojarzenie z gestem umywania stóp przez Jezusa podczas ostatniej wieczerzy. Taki zwyczaj umywania nóg swoim siostrom oraz całowania ich miała św. Klara. Jej biograf pisze:

bardzo często myła nogi siostrom służebnym, które wracały z pola i umywszy je, całowała. Pewnego razu myła nogi jednej z tych służebnych i podczas gdy miała je ucałować, tamta, nie mogąc patrzeć na tak wielkie upokorzenie, porwała nogę i w tym odruchu uderzyła swą panią w twarz. Ale ona łagodnie przytrzymała nogę służebnej i dokładnie ucałowała ją w stopę $e^{21}$.

Franciszek w Liście do wiernych mówi o „chęci ucałowania stóp adresatów". Można łatwo sobie wyobrazić, że jako człowiek dbający o zgodność słów z życiem Franciszek, podobnie jak Klara, wdrażał to pragnienie także w życie. Warto tu zauważyć, że tak jak Jezus w Ewangelii Jana, także Franciszek tutaj nie tylko daje pouczenie o konieczności służenia w uniżeniu, ale sam definiuje siebie jako sługa najmniejszy.

Obraz całowania stóp obok ich umywania podkreśla sposób wykonywania posługi: z miłością. Umywanie nóg pana należało do obowiązków sługi, ale całowanie ich już nie. Ten, kto czynił jeden i drugi gest, wyrażał, że służy nie z przymusu, ale świadomie i dobrowolnie, z miłością. W minoritas chodzi o taką posługę: z pokorą i miłością. Wówczas nie jest ona tylko wykonaniem obowiązku, ale nabiera mocy świadectwa zdolnego poruszyć serce tego, komu oddaje przysługę.

W drugim fragmencie Franciszek używa obrazu „bycia pod stopami innych”. Na skojarzenie z gestem umycia nóg przez Jezusa pozwala obok podobieństwa obrazu fakt, że podobnie jak w Napomnieniu 4, w którym znajduje się wyraźne odniesienie do trzynastego rozdziału Ewangelii Jana, także tutaj słowa te są skierowane do przełożonych. Święty z Asyżu chce, aby ci, którzy sprawują władzę, byli sługami innych, posuwając się aż do „bycia pod ich stopami”. W ostatnim rozdziale Reguły zatwierdzonej używa

\footnotetext{
${ }^{21} \operatorname{Lg} 12$.
} 
tego obrazu w stosunku do wszystkich braci: „....abyśmy zawsze poddani i położeni pod stopy tego świętego Kościoła, ugruntowani w wierze katolickiej, zachowywali ubóstwo i pokorę, i świętą Ewangelię Pana naszego Jezusa Chrystusa”22. „Być pod stopami innych” oznacza zatem „być poddanym, uległym innym". Idea ta pojawia się często w pismach św. Franciszka. W sposób bezpośredni połączona z minoritas występuje w 1 Reg 7, 1-2:

Wszyscy bracia, w jakichkolwiek miejscach przebywają u kogoś, aby służyć albo pracować, nie mogą być rządcami ani urzędnikami, ani obejmować stanowisk kierowniczych w domach, gdzie służą. Niech nie przyjmują funkcji, która spowodowałaby zgorszenie lub wyrządziłaby szkodę ich duszy. Lecz niech będą mniejsi i poddani wszystkim, którzy przebywają w tym samym domu².

„Być mniejszym” oznacza zatem także „być poddany wszystkim”, „być pod stopami innych”. Nie chodzi tu o naiwną uległość lub służalczość, ale świadome wybieranie ostatniego miejsca w środowisku, w którym się przebywa. W hymnie chrystologicznym z listu do Filipian Paweł wyraża tę postawę Chrystusa w słowach: „uznany za człowieka, uniżył samego siebie, stawszy się posłusznym aż do śmierci - i to śmierci krzyżowej". Przyjmując haniebną śmierć na krzyżu, Chrystus prawdziwie zajął ostatnie miejsce, pod stopami wszystkich: miejsce ostatniego grzesznika, który wchodzi w stan ekstremalnego oddalenia od Boga. Z takiego miejsca może On objąć każdego człowieka, nawet największego grzesznika, aby przywrócić go do jedności z Bogiem² ${ }^{24}$ Jeśli zatem Chrystus Sługa zajmuje takie miejsce, to brat mniejszy wybiera je także, ze świadomością, że nie jest ono najgorsze, ale uprzywilejowane, aby móc gło-

222 Reg 12: „ut semper subditi et subiecti pedibus eiusdem sanctae Ecclesiae stabiles in fide catholica paupertatem et humilitatem et sanctum evangelium Domini nostri Jesu Christi... observemus".

${ }^{23}$ „Omnes fratres, in quibuscumque locis steterint apud alios ad serviendum vel laborandum non sint camerarii neque cancellarii neque praesint in domibus in quibus serviunt; nec recipiant aliquod officium, quod scandalum generet vel animae suae faciat detrimentum; sed s i nt mi nores et subditi omnibus, qui in eadem domo sunt". Por. także: 1 Reg 16, 5-6; T 19; 2 Lw 47.

${ }^{24}$ W podwójnym sensie: 1 . Chrystus, zajmując ostatnie miejsce, prawdziwie zstąpił do piekieł, aby Jego zbawienie dotarło do w s zy s tk i ch; nie ma takiego grzesznika, do którego zbawienie Chrystusa nie mogłoby dotrzeć; 2 . Z pozycji ostatniego miejsca Chrystus ofiaruje zbawienie jako d ar, a nie jako p r zy mu s; nie narzuca go, ale szanuje wolność każdego, ułatwiając w ten sposób przyjęcie go przez w s zystkich. 
sić Dobrą Nowinę. Prawda o zbawieniu podana z takiej pozycji może dotrzeć do każdego, nawet najbardziej oddalonego od Boga.

\section{Franciszkowe rozumienie minor według Łk 17, 10}

Ostatni z wyodrębnionych fragmentów pism św. Franciszka nawiązuje do jednego z pouczeń Jezusa przytoczonych jedynie przez ewangelistę Łukasza. Także to pouczenie dotyczy postawy służenia. Zawiera ideę pokornego uznania statusu sługi wobec Boga, czuwania nad tym, aby nie zająć Jego miejsca. To On jest Panem i tę świadomość uczeń Chrystusa ma mieć zawsze, także wtedy, gdy wykona dobrze swoje zadanie. Nie powinien wówczas oczekiwać nagrody od Pana w postaci wywyższenia lub przywilejów: „kto z was, mając sługę, powie mu, gdy on wróci z pola: "przyjdź i siądź do stołu»", ale z pokorą zachować swoją pozycję sługi, który nieustannie gotowy jest wypełniać to, co zostanie mu zlecone. Uczeń Chrystusa ma mieć świadomość, że wobec Niego zawsze pozostanie sługą, także wówczas, gdy dobrze wykona polecone mu zadania. Podkreśla to określenie użyte w stosunku do sługi: nieuży te c zny: „tak i wy mówcie, gdy uczynicie wszystko, co wam polecono: słudzy ni e uży te c zni j e s teś my ". Użyty w Ewangelii termin grecki óx $\rho \varepsilon \tilde{i} o \varsigma$ oznacza dokładnie ni e ko ni e c z ny. Nie ma więc sensu pogardliwego czy lekceważącego wobec osoby, ale wyraża raczej ideę jej relatywnej konieczności: „to, co czyni sługa, także on sam, ma swoją wartość, ale sam sługa nie jest niezbędny. To, co on czyni dla pana, może wykonać także inny sługa równie dobrze jak on”. Wydaje się, że to uznanie własnej „niekonieczności” chce podkreślić Franciszek, kiedy określa siebie i braci pojęciem zaczerpniętym z Ewangelii: „my wszyscy bracia mniejsi, słudzy nieużyteczni" 25 .

Warto zauważyć także kontekst, w jakim święty z Asyżu używa tego określenia. Po modlitwie dziękczynnej skierowanej do Boga za dzieło stworzenia i za wszelkie dobro, którego nieustannie udziela ludziom, oraz po prośbie skierowanej do wszystkich świętych, począwszy od Najświętszej Dziewicy Maryi, aby również oni składali dzięki Bogu, Franciszek zwra-

251 Reg 23, 7: „nos omnes fratres minores, servi inutiles”. 
ca się do wszystkich ludzi z zachętą, aby wiernie służyli temu dobremu i nad wyraz hojnemu Bogu. Po wymienieniu wszystkich możliwych stanów, począwszy od kapłanów, a skończywszy na „wszystkich ludziach na całej ziemi, którzy są i będą", Franciszek wymienia siebie i swoich braci jako autorów zachęty. Formułuje ją jednak nie z pozycji władzy ani z pozycji kogoś, kto już osiągnął metę, ale z pozycji sług, którzy zajmują ostatnie miejsce w całej hierarchii wymienionych stanów: „my wszyscy bracia mniejsi, słudzy nieużyteczni, pokornie prosimy i błagamy, abyśmy wszyscy wytrwali w prawdziwej wierze i pokucie".

Tę samą ideę Franciszek wyraża w liście skierowanym do całego zakonu, stosując ją do siebie samego. Kończy go, definiując się jako „Człowiek nieużyteczny i niegodne stworzenie Pana Boga” ${ }^{26}$. W Regule umiejscawia cały zakon na ostatnim miejscu wobec całej ludzkości, w Liście do zakonu stawia siebie samego na ostatnim miejscu wobec wszystkich braci.

Minoritas wiąże się zatem z pokorną świadomością własnej niekonieczności zarówno w porządku istnienia, jak i działania. Brat mniejszy ma świadomość, że choć jest niepowtarzalnym stworzeniem Boga, to jednak nie jest niezastąpiony w Jego planie zbawienia. To, co czyni, ma swoją wartość, ale on sam nie jest niezbędny do wykonania powierzonego mu zadania. Może je wykonać także ktoś inny. Brat mniejszy ma pamiętać o swoim statusie je dy n i e sługi, którym na zawsze pozostanie wobec Pana. Dlatego nie dąży do zajęcia Jego miejsca, gromadząc przywileje, prawa i tytuły czy też wspinając się po kolejnych szczeblach kariery, ale pokornie wypełnia polecone mu zadania, mając świadomość, że czyni tylko to, co do niego należy.

\section{Zakończenie}

Zakon założony przez Franciszka z Asyżu nie przypadkowo otrzymał nazwę braci mniejszych. Nie pochodzi ona ani od koloru habitu (np. bracia brązowi, Grayfriars), ani od miejsca założenia zakonu

26 LZ 47: „Ego frater Franciscus homo inutilis et indigna creatura Domini Dei”. 
(np. bracia z Asyżu), ani od rodzaju posługi lub wykonywanej pracy (np. bracia szpitalni, zakon kaznodziejski, misjonarze), ale od sposobu bycia, od stylu życia. Określa go w istotnej mierze pojęcie minoritas. Próby refleksji nad jego znaczeniem powinny zatem stanowić nieustanny wysiłek wszystkich braci mniejszych. Od tego bowiem w dużym stopniu zależy, na ile będą żyć charyzmatem zakonu założonego przez Franciszka z Asyżu.

Powyższą próbę dotarcia do tego, jak on sam rozumiał minoritas próbę skromną, bo ograniczoną tylko do jednej perspektywy: chrystologicznej - można podsumować następująco: bracia św. Franciszka mają być mniejsi, tzn.:

1) służyć bez chęci dominowania nad innymi,

2) rezygnować dobrowolnie z przysługujących im przywilejów,

3) żyć bez szukania zabezpieczeń, ale zdając się na Opatrzność Bożą,

4) być gotowymi do podejmowania takich czynności, które inni niechętnie wykonują,

5) służyć z pokorą i miłością,

6) starać się zajmować ostatnie miejsce w swoim środowisku,

7) mieć świadomość własnej „niekonieczności”.

Wymienione cechy wynikają z nauczania i z życia Chrystusa Sługi. Franciszek uchwycił je dzięki ciągłej lekturze i medytacji Ewangelii. Taka jest również droga dla każdego brata mniejszego, aby je ostatecznie poznać, osobiście przyjąć i żyć nimi na co dzień. 


\section{Streszczenie}

Zakon założony przez Franciszka z Asyżu nieprzypadkowo otrzymał nazwę braci mniejszych. Nie pochodzi ona ani od koloru habitu, ani od miejsca założenia zakonu, ani od rodzaju posługi lub wykonywanej pracy (np. bracia szpitalni, zakon kaznodziejski, misjonarze), ale od sposobu bycia, od stylu życia. Określa go w istotnej mierze pojęcie minoritas. Tekst stanowi próbę dotarcia do tego, jak je rozumiał sam Franciszek. Rozważania prowadzone w perspektywie chrystologicznej kończą się następującymi wnioskami: bracia św. Franciszka mają być mniejsi, tzn.: służyć bez chęci dominowania nad innymi, rezygnować dobrowolnie z przysługujących im przywilejów, żyć bez szukania zabezpieczeń, ale zdając się na opatrzność Bożą, być gotowi do podejmowania takich czynności, które inni niechętnie wykonują, służyć z pokorą i miłością, starać się zajmować ostatnie miejsce w swoim środowisku, mieć świadomość własnej niekonieczności.

Słowa kluczowe: św. Franciszek z Asyżu, bracia mniejsi, minoritas, chrystologia

\section{Minority according to St. Francis of Assisi in a Christological perspective.}

The order founded by St. Francis of Assisi has not been accidentally given the name of Friars Minor. It comes neither from the color of the habit, the place of establishment of the order, nor the type of service or job, but a way of being and living. All the attempts to read how Francis understood the minority from the Christological perspective can be summarized as follows: Brothers of St. Francis will be minor, i.e. serve no desire to dominate others, to give up voluntarily exercise their privilege, to live without the hassles of security, but to rely on Divine Providence. It also means to be ready to take such steps that others are reluctant to carry out, to serve with humility and love, and try to occupy the last place in their environment and to be aware of own non-necessity.

Keywords: St. Francis of Assisi, Friars Minor, minoritas, chrystology 